\title{
Higher Education and Productivity in China
}

\author{
Shushu $\mathrm{Li}^{1}$ \\ Chinese Academy of \\ Sciences
}

\author{
$\mathrm{Li} \mathrm{Fu}^{2}$ \\ Renmin University of \\ China
}

\author{
Yong $\mathrm{Ma}^{3}$ \\ Renmin University of \\ China
}

\begin{abstract}
This paper examines the impact of higher education on total factor productivity in China using province-level panel data over the period of 1995-2016. The results show that higher education has a significant U-shaped impact on total factor productivity with a threshold value of 0.323 , indicating that higher education development would have a positive impact on total factor productivity after the ratio of college graduates to population exceeds $32.3 \%$. Further analysis reveals that the impact of higher education on total factor productivity is mainly through the Technical Efficiency channel and the Scale Efficiency channel. Moreover, according to the results of the paper, higher education in most provinces of China's is still below the threshold level, suggesting that developing higher education would be an important policy strategy to promote productivity in China.
\end{abstract}

\section{Keywords}

Higher Education • Total Factor Productivity $\bullet$ China

\footnotetext{
* This research was supported by National Natural Science Foundation of China (No.71741030).

${ }^{1}$ Institutes of Science and Development, Chinese Academy of Sciences, Beijing 100190, China. Email: lishushu@ @asipm.ac.cn

${ }^{2}$ School of Finance, Renmin University of China, Beijing 100872, China. Email: fulifly2008@126.com

${ }^{3}$ Correspondence to: Yong Ma, China Financial Policy Research Centre, School of Finance, Renmin University of China, Beijing 100872, China. Email: mayongmail@ ruc.edu.cn

Citation: Li, S. S., Fu, L., \& Ma, Y. (2018). Higher Education and Productivity in China. Educational Sciences: Theory \& Practice, 18(5), 1863-1875. http://dx.doi.org/10.12738/estp.2018.5.087
} 
Higher education plays an important role in both economic and social development, especially for fastgrowing developing countries like China. In the twenty-first century, when economic and social development is even more complex, there is an increasing need for more well-educated labour that are best associated with higher education. As a result, the development of higher education and its connections with economic and social development remain to be central issues on the agenda of policymakers. Among these issues, a key issue that is important, but not yet fully resolved, is whether and how higher education may affect productivity thus affect economic growth.

Despite the inadequacy of the literature on a direct examination of the higher education-productivity nexus, a large strand of literature has discussed the role of human capital in economy growth, where education is considered as an important form of human capital. In an early study, Nelson and Phelps (1966) argue that human capital's impact on total factor productivity contributes to economic growth. In the study of Mankiw, Romer, Weil, (1992), the accumulation of human capital has a positive effect on economic growth. As regards the empirical literature, however, the results are somewhat mixed (Barro, 1991; Mankiw et al., 1992; Benhabib and Spiegel, 1994; Nasrul, 1995; Pritchett, 2001). According to Temple (1999) and Rogers (2008), differences in education quality, specific characteristics and market structures across countries may play a role in the uncertain effect of human capital on economic growth. Other explanations include data reasons like misspecification and measurement error and lack of data quality, especially for the transition economies (Benhabib and Spiegel, 1994; Hanushek and Kimko, 2000; Krueger and Lindahl, 2001; Cohen and Soto, 2007; Ahsan and Haque, 2017). In the study of Romer (1990), the level of human capital can explain the economic growth for higher level of human capital enhance productivity, while the improvement of basic knowledge like literacy rate only plays a limited role. Hansen (1999) also confirms that, the positive impact of human capital on growth only occurs when the economy develops into a certain level. Levin (1991) provide possible ways that higher education may have a positive impact on productivity for given resource levels. Benhabib and Spiegel (1994) find that education affects technology improvement and results in changes in economic growth. Kremer, Bick, \& Nautz (2013) extends Hansen's model by using dynamic panel data model. In the study of Schündeln and Playforth (2014), social returns to human capital should also be taken into consideration.

To assess the effect of human capital on economic growth, different estimation methods and data sets have been used in the existing literature. In the study of Krueger and Lindahl (2001), initial level of education significantly affects growth in low and middle income countries, but this does not hold in developed countries. Yao and Zhang (2001) use province-level panel data model and find that human capital is positively associated with economic growth. In the study of Ding and Knight (2011), the authors use Generalized Method of Moments (GMM) method to examine the effects of human capital accumulation on economic growth and confirm a positive effect of human capital on economic growth. However, the crosssection regressions in Chen and Fleisher (1996) and the panel estimations in Wei, Liu, Song, \& Romilly (2001), Chi (2008) and Li, Lai, Wang, \& Zhao (2016) do not find significant impacts of human capital on economic growth. As for the relationship among human capital, productivity and economic growth in China, a direct examination of how higher education may affect total factor productivity seems to be largely absent, 
although there are studies showing that higher education leads to a large gap in regional growth rate (Chen and Fleisher, 1996; Fleisher and Chen, 1997; Demurger, 2001), or that higher educated workers contributes to higher marginal products (Fleisher and Wang, 2004; Fleisher et al., 2006), or that higher education contributes to economic growth (Song, 2018; Zhang and Zhuang, 2011).

To sum up, while there is a large body of literature on the relationships between human capital and economic growth or productivity, very few have discussed whether and how higher education may affect productivity, which leaves a major gap in our understanding of the relationships between higher education, productivity and economic growth. Against this background, in this paper we attempt to make a first step in addressing this inadequacy by using province-level panel data from China over the period of 1995-2016. The main contributions of this paper can be summarized as follows.

First, while a large body of literature have discussed the role of education in economic development, very few have directly investigated the relationship between higher education and productivity, especially for developing countries like China. This paper attempts to fill this gap partially by providing empirical evidences on the relationships between higher education and various indicators of productivity using panel data estimation. This helps to establish a direct link between higher education and productivity, which in turn extends our understanding of the role of higher education in economic development.

Second, we find new evidences showing that there exists a U-shaped relationship between higher education and total factor productivity, which is in contrast to the majority of the previous studies which typically assume linear relationships in their analysis. As one can easily see, a U-shaped relationship means that productivity can be improved only after the level of higher education reaches a threshold value, pointing to an even more important role of developing higher education than the traditional linear positive relationship documented in the previous literature.

Third, we show that the U-shaped relationship between higher education and total factor productivity remains quite robust after controlling for a variety of macroeconomic variables such as CPI, real GDP per capita, industry structure, infrastructure, trade openness, real GDP, and government size. Moreover, our main results are also shown to be robust under different estimation methods, which further strengthens the validity of our conclusions.

The rest of the paper is organized as follows. Section 2 describes the data and discusses the methodology. Section 3 presents the empirical findings. Section 4 concludes the paper.

\section{Methodology and Data}

\section{Data and variables}

To investigate the relationship between higher education and productivity growth, we use data of 30 provinces of China covering the period from 1995 to 2016. 
Our dependent variable is Total Factor Productivity (TFP), which is calculated by Malmquist productivity index (MPI) and consists of four sub-indices: Technical Efficiency (TE), Technical Progress (TP), Pure Technical Efficiency (PTE), Scale Efficiency (SE). MPI measures the productivity changes along with time variations and can be decomposed into changes in efficiency and technology with DEA-like nonparametric approach. The MPI can be expressed in terms of distance function (E) as Equation (1) and Equation (2) using the observations at time $\mathrm{t}$ and $\mathrm{t}+1$ :

$$
\begin{gathered}
M P I_{I}^{t}=\frac{E_{I}^{t}\left(x^{t+1}, y^{t+1}\right)}{E_{I}^{t}\left(x^{t}, y^{t}\right)} \\
M P I_{I}^{t+1}=\frac{E_{I}^{t+1}\left(x^{t+1}, y^{t+1}\right)}{E_{I}^{t+1}\left(x^{t}, y^{t}\right)}
\end{gathered}
$$

The geometric mean of MPI in Eqs. (1) and (2) leads to the following equation:

$$
M P I_{I}^{G}=\left(M P I_{I}^{t} M P I_{I}^{t+1}\right)^{1 / 2}=\left[\left(\frac{E_{I}^{t}\left(x^{t+1}, y^{t+1}\right)}{E_{I}^{t}\left(x^{t}, y^{t}\right)}\right) \cdot\left(\frac{E_{I}^{t+1}\left(x^{t+1}, y^{t+1}\right)}{E_{I}^{t+1}\left(x^{t}, y^{t}\right)}\right)\right]^{\frac{1}{2}}
$$

The input oriented geometric mean of MPI can be decomposed using the concept of input oriented technical progress (TP) and input oriented technical efficiency (TE) as given by Equation (4):

$$
M P I_{I}^{G}=\left(T E_{I}\right) \cdot\left(T P_{I}^{G}\right)=\left(\frac{E_{I}^{t+1}\left(x^{t+1}, y^{t+1}\right)}{E_{I}^{t}\left(x^{t}, y^{t}\right)}\right) \cdot\left[\left(\frac{E_{I}^{t}\left(x^{t}, y^{t}\right)}{E_{I}^{t+1}\left(x^{t}, y^{t}\right)}\right) \cdot\left(\frac{E_{I}^{t}\left(x^{t}, y^{t}\right)}{E_{I}^{t+1}\left(x^{t+1}, y^{t+1}\right)}\right)\right]^{1 / 2}
$$

where the first and second terms in Eq. (4) represent the technical efficiency (TE) and the technical progress (TP), respectively. In addition, by utilizing both CRS and VRS DEA frontiers to estimate the distance functions in Eq. (4), the technical efficiency can be further decomposed into scale efficiency (SE) and pure technical efficiency (PTE) as follows:

$$
\begin{aligned}
& S E=\left[\frac{E_{v r s}^{t+1}\left(x^{t+1}, y^{t+1}\right) / E_{c r s}^{t+1}\left(x^{t+1}, y^{t+1}\right)}{E_{v r s}^{t+1}\left(x^{t}, y^{t}\right) / E_{c r s}^{t+1}\left(x^{t}, y^{t}\right)} \cdot \frac{E_{v r s}^{t}\left(x^{t+1}, y^{t+1}\right) / E_{c r s}^{t}\left(x^{t+1}, y^{t+1}\right)}{E_{v r s}^{t}\left(x^{t}, y^{t}\right) / E_{v r s}^{t}\left(x^{t}, y^{t}\right)}\right]^{1 / 2} \\
& P T E=\frac{E_{v r s}^{t+1}\left(x^{t+1}, y^{t+1}\right)}{E_{c r s}^{t}\left(x^{t}, y^{t}\right)}
\end{aligned}
$$

A more detailed explanation of the calculation method of Malmquist productivity index (Caves et al., 1982; Fare et al., 1994; Jeanneney et al., 2006; Han and Shen, 2015).

The key explanatory variable in our study is higher education (EDU) and its quadratic term (EDU2). As is common in the literature, we use college graduates as a share of local population based on the 2010 census to represent the level of higher education development. As shown in Figs. 1 and 2, these has witnessed a significant improvement of higher education development for each province in China over the sample period of 1995-2006, where the average value of higher education development (as measured by the ratio of college graduates to local population) almost tripled in 2016 (Fig. 2) with an average value of 0.244 than that in 1995 (Fig. 1) with an average value of 0.087. 


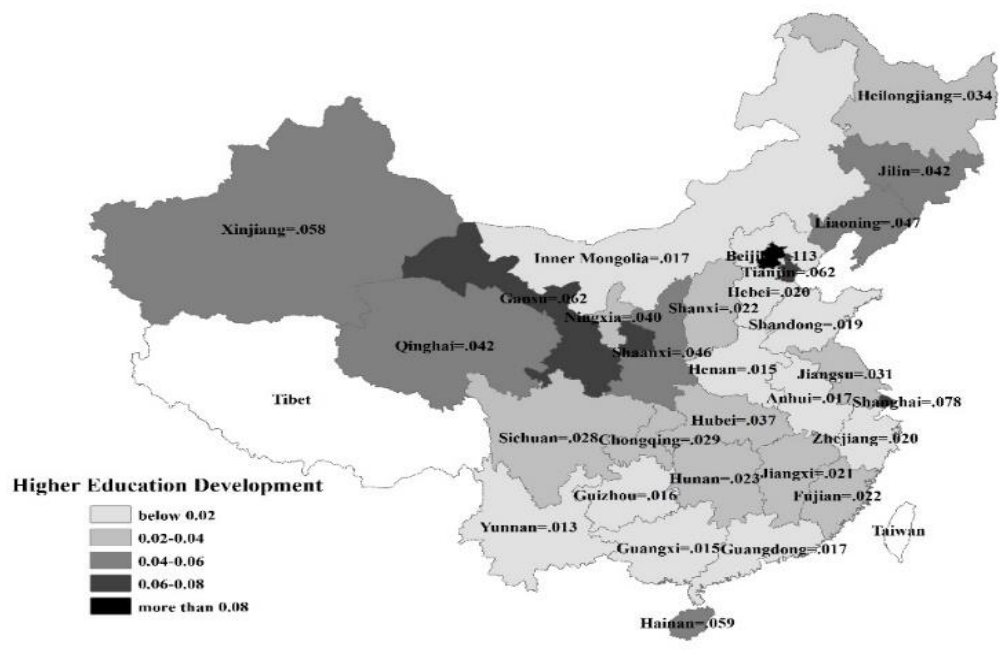

Figure 1. Higher education development for each province in 1995.

Note. (1) Higher education development is measured by the ratio of college graduates to local population. (2) Tibet and Taiwan are not included in the analysis due to data availability.

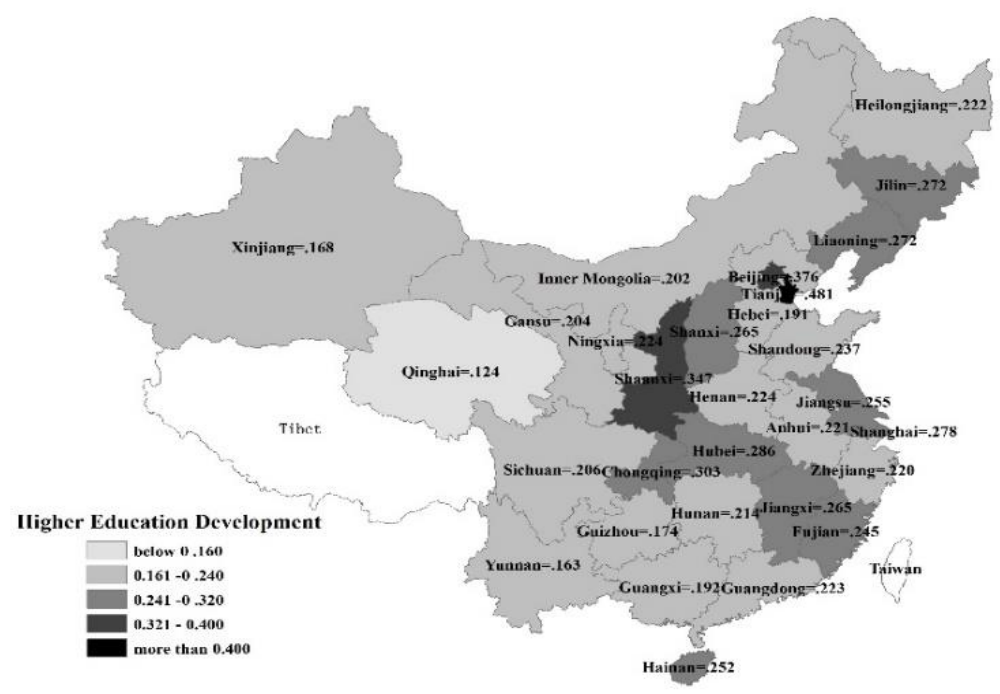

Figure 2. Higher education development for each province in 2016.

Note: (1) Higher education development is measured by the ratio of college graduates to local population. (2) Tibet and Taiwan are not included in the analysis due to data availability. 
Finally, to ensure our results are not driven by omitted variables, we also include a variety of control variables that may affect total factor productivity. In particular, the controls that we use include: (1) Inflation, measured by consumer price index (CPI); (2) Economic development, measured by real GDP per capita (RGDPPC); (3) Industry structure (INDUSTRU), measured by the value of secondary and tertiary industries to GDP ratio; (4) Infrastructure development (INFRA), measured by the length of road per 100 squared kilometers (Fleisher et al., 2007); (5) Economic size (RGDP), measured by log of regional real GDP; (6) Trade openness (OPEN), measured by the sum of export and import to GDP ratio; (7) Government size (GOVERN), measured by government expenditures as a percentage of GDP. These indicators capture a large variety of potential differences across different provinces in China. All the data of the variables are obtained from National Bureau of Statistics of China. Table 1 reports the summary statistics of the data.

Table 1

Summary Statistics

\begin{tabular}{llccccc}
\hline Variable & \multicolumn{1}{c}{ Definition } & Obs. & Mean & Std. Dev. & Min & Max \\
\hline$T F P$ & Total factor productivity & 660 & 0.012 & 0.089 & -0.316 & 0.538 \\
$T E$ & Technical Efficiency & 660 & 0.997 & 0.093 & 0.512 & 1.904 \\
$T P$ & Technical Progress & 660 & 1.017 & 0.086 & 0.449 & 2.194 \\
$P T E$ & Pure Technical Efficiency & 660 & 0.995 & 0.078 & 0.423 & 1.456 \\
SE & Scale Efficiency & 660 & 1.003 & 0.064 & 0.586 & 1.671 \\
$E D U$ & Higher education & 660 & 0.139 & 0.092 & 0.013 & 0.481 \\
CPI & Consumer price index & 660 & 3.011 & 4.051 & -3.600 & 21.400 \\
RGDPPC & Real GDP per capita & 660 & 8.133 & 0.814 & 6.247 & 9.877 \\
$I N D U S T R U$ & Industry structure & 660 & 0.855 & 0.079 & 0.621 & 0.996 \\
$I N F R A$ & Infrastructure development & 660 & 1.145 & 1.595 & 0.068 & 10.271 \\
RGDP & Economic size & 660 & 3.061 & 0.498 & 1.662 & 4.141 \\
OPEN & Trade openness & 660 & 0.304 & 0.385 & 0.032 & 2.043 \\
GOVERN & Government size & 660 & 0.175 & 0.090 & 0.049 & 0.660 \\
\hline
\end{tabular}

\section{Model and estimation methodology}

To examine the impact of higher education on total factor productivity, we begin with estimating the following regression model:

$$
\operatorname{TFP}_{i, t}=\alpha+\beta E D U_{i, t}+\gamma E D U_{i, t}^{2}+\sum_{k} \theta_{k} \operatorname{CONTROLS}_{i, t}^{k}+\varepsilon_{i, t}
$$

where $T F P_{i, t}$ denotes TFP for province $i$ and in year $t . E D U_{i, t}$ is the higher education development indicator as defined earlier. $E D U_{i, t}^{2}$ is the quadratic term of $E D U_{i, t}$, which is included to capture the potential non-linear effect of higher education on TFP. CONTROLS ${ }_{i, t}^{k}$ is the vector of control variables as defined before. $\varepsilon_{\mathrm{i}, \mathrm{t}}$ is the error term.

To estimate the model, both fixed effects (FE) and random effects (RE) estimator are used in the first place. As is standard in the literature, the choice between fixed effects (FE) and random effects (RE) is decided by Hausman test. Further, considering that unobserved province-specific effect is typically present in panel data models, we also use generalized method of moments (GMM) for robustness. As the firstdifferenced GMM estimator faces the risk of failing to exploit all of the available moment conditions, we use system GMM estimator suggested. The system GMM estimator adds available instrumental variables 
and uses both level and first-differenced regressions in the estimation. Therefore, system GMM is able to control province-specific unobserved heterogeneity. Moreover, system GMM also helps to eliminate the endogeneity of the independent variables and reduce finite sample bias. After including unobserved province-specific effect, Eq. (1) can be rewritten as:

$$
\operatorname{TFP}_{i, t}=\alpha_{0}+\beta E D U_{i, t}+\gamma E D U_{i, t}^{2}+\sum_{k} \theta_{k} \operatorname{CONTROL}_{i, t}^{k}+v_{i}+\mu_{t}+\varepsilon_{i, t}
$$

Finally, it should be noted that, to ensure the validity of the instruments in GMM estimation, Arellano and Bond (1991) propose Sargan test with the null hypothesis that there is no correlation between residuals and instruments and second-order serial correlation test (i.e., AR(2) test) with the null hypothesis that there is no second-order serial correlation in the errors. To ensure adequate model specification, both the null hypotheses of the Sargan test and the AR (2) test should not be rejected.

\section{Empirical Results}

Table 2

Higher Education and TFP: Baseline Results.

\begin{tabular}{|c|c|c|c|}
\hline Estimator $\longrightarrow$ & OLS & $\mathrm{FE}$ & RE \\
\hline \multirow{2}{*}{ Variables $\downarrow \rightarrow$} & $T F P$ & $T F P$ & $T F P$ \\
\hline & (1) & (2) & (3) \\
\hline \multirow[t]{2}{*}{$E D U$} & $-0.340^{*}$ & $-1.301 * * *$ & $-0.346^{*}$ \\
\hline & $(0.182)$ & $(0.317)$ & $(0.183)$ \\
\hline \multirow[t]{2}{*}{$E D U^{2}$} & $0.691 *$ & $2.011 * * *$ & $0.696^{* *} *$ \\
\hline & $(0.353)$ & $(0.530)$ & $(0.354)$ \\
\hline \multirow[t]{2}{*}{$C P I$} & $0.006^{* *} *$ & 0.004 & $0.006^{* * *}$ \\
\hline & $(0.003)$ & $(0.003)$ & $(0.003)$ \\
\hline \multirow[t]{2}{*}{$R G D P P C$} & $0.057 * * *$ & $0.227 * * *$ & $0.058 * * *$ \\
\hline & $(0.015)$ & $(0.054)$ & $(0.015)$ \\
\hline \multirow[t]{2}{*}{ INDUSTRU } & $-0.219 * * *$ & -0.223 & $-0.217 * * *$ \\
\hline & $(0.080)$ & $(0.170)$ & $(0.080)$ \\
\hline \multirow[t]{2}{*}{ INFRA } & 0.003 & 0.003 & 0.003 \\
\hline & $(0.003)$ & $(0.006)$ & $(0.003)$ \\
\hline \multirow[t]{2}{*}{ OPEN } & $0.022 *$ & 0.045 & $0.022^{*}$ \\
\hline & $(0.012)$ & $(0.029)$ & $(0.012)$ \\
\hline \multirow[t]{2}{*}{$R G D P$} & -0.021 & $-0.306^{* *}$ & -0.022 \\
\hline & $(0.014)$ & $(0.124)$ & $(0.014)$ \\
\hline \multirow[t]{2}{*}{ GOVERN } & 0.062 & $-0.315^{* *}$ & 0.057 \\
\hline & $(0.085)$ & $(0.125)$ & $(0.086)$ \\
\hline \multirow[t]{2}{*}{ Constant } & $-0.216^{* * *}$ & $-0.559 * *$ & $-0.270 * *$ \\
\hline & $(0.097)$ & $(0.271)$ & $(0.118)$ \\
\hline F/Wald test & $10.80 * * *$ & $10.01 * * *$ & $322.77 * * *$ \\
\hline $\mathrm{R}^{2}$ & 0.31 & 0.27 & 0.31 \\
\hline Observations & 660 & 660 & 660 \\
\hline
\end{tabular}

Note. (1) Standard errors are in parentheses; (2) *,** and *** denote significant at the level of $10 \%, 5 \%$ and $1 \%$, respectively. 


\section{Regressions results for TFP}

Table 2 presents the estimation results for TFP. The first column reports the regression results for Eq. (7) from the pooled OLS estimators. The second and third columns report the results from fixed effects and random effects, respectively. According to results of Hausman test, the null hypothesis is rejected thus the fixed effects results are more precise.

As one can see, the level and quadratic terms of TFP are estimated to be significantly positive and significantly negative, respectively. This indicates a significant $\mathrm{U}$-shaped relationship between higher education and TFP. That is, there exists a threshold value of higher education development, after which the negative impact of higher education on TFP turns positive. According to the results obtained by the FE estimator, which is considered to be more precise as explained earlier, the estimated threshold value of higher education development is 0.323 . However, only three provinces (i.e., Beijing, Tianjin and Shaanxi) in our sample exceed the threshold value in 2016 (see Figure 2), suggesting that most provinces of China still need to further develop higher education to improve productivity. As for the control variables, the coefficients on real GDP per capita $(R G D P P C)$ are estimated to be significantly positive in pooled OLS and fixed effects regressions, implying fast economic growth contributes to higher productivity. On the contrary, the coefficients on economic size $(R G D P)$ and government size $(G O V E R N)$ are estimated to be significantly negative, implying that an increase in economic and government would lead to lower productivity.

Table 3

Higher education and sub-indicators of TFP.

\begin{tabular}{|c|c|c|c|c|}
\hline Panel data estimator $\longrightarrow$ & $\mathrm{RE}$ & $\mathrm{RE}$ & $\mathrm{RE}$ & FE \\
\hline \multirow[t]{2}{*}{ Variables $\downarrow \rightarrow$} & $T E$ & $T P$ & PTE & $S E$ \\
\hline & (1) & (2) & (3) & (4) \\
\hline \multirow[t]{2}{*}{$E D U$} & -0.312 & -0.114 & 0.092 & $-1.234 * * *$ \\
\hline & $(0.211)$ & $(0.174)$ & $(0.182)$ & $(0.263)$ \\
\hline \multirow[t]{2}{*}{$E D U^{2}$} & $0.818 * *$ & 0.007 & 0.055 & $1.605 * * *$ \\
\hline & $(0.408)$ & $(0.330)$ & $(0.354)$ & $(0.440)$ \\
\hline \multirow[t]{2}{*}{$C P I$} & $0.008 * *$ & -0.001 & 0.004 & 0.003 \\
\hline & $(0.003)$ & (0.003) & (0.003) & $(0.003)$ \\
\hline \multirow[t]{2}{*}{$R G D P P C$} & 0.026 & $0.029 * *$ & $0.025^{*}$ & $0.096 * *$ \\
\hline & $(0.017)$ & $(0.014)$ & $(0.015)$ & $(0.045)$ \\
\hline \multirow[t]{2}{*}{ INDUSTRU } & $-0.171^{*}$ & -0.045 & $-0.151^{*}$ & $-0.275^{*}$ \\
\hline & $(0.092)$ & $(0.077)$ & $(0.080)$ & $(0.141)$ \\
\hline \multirow[t]{2}{*}{ INFRA } & -0.004 & $0.010 * * *$ & $-0.005^{*}$ & 0.004 \\
\hline & $(0.003)$ & $(0.003)$ & $(0.003)$ & (0.005) \\
\hline \multirow[t]{2}{*}{ OPEN } & $0.030 * *$ & 0.009 & 0.014 & 0.009 \\
\hline & (0.014) & (0.012) & (0.012) & (0.024) \\
\hline \multirow[t]{2}{*}{$R G D P$} & -0.023 & 0.000 & -0.007 & -0.085 \\
\hline & $(0.016)$ & $(0.014)$ & (0.014) & $(0.103)$ \\
\hline \multirow[t]{2}{*}{ GOVERN } & 0.023 & 0.021 & 0.135 & $-0.349 * * *$ \\
\hline & $(0.099)$ & $(0.081)$ & $(0.086)$ & $(0.103)$ \\
\hline \multirow[t]{2}{*}{ Constant } & $1.022 * * *$ & $0.732 * * *$ & $0.869 * * *$ & $0.970 * * *$ \\
\hline & $(0.135)$ & $(0.112)$ & $(0.117)$ & $(0.225)$ \\
\hline F/Wald test & 151.14*** & $452.85^{* * * *}$ & $101.07 * * *$ & 4.66 *** \\
\hline $\mathrm{R}^{2}$ & 0.18 & 0.41 & 0.12 & 0.11 \\
\hline Observations & 660 & 660 & 660 & 660 \\
\hline
\end{tabular}

Note. (1) Standard errors are in parentheses; (2) *, ** and *** denote significant at the level of $10 \%, 5 \%$ and $1 \%$, respectively. 


\section{Regressions results for sub-indicators of TFP}

The results obtained by using Technical Efficiency (TE), Technical Progress (TP), Pure Technical Efficiency (PTE), Scale Efficiency (SE) as the dependent variables are presented in Table 3.

According to the results of Hausman test, the null hypothesis of the regressions for TE, TP and PTE cannot be rejected, thus the results of random effects are more precise. As for the results for SE, the reverse is true: the results of fixed effects are found to be more precise according to the Hausman test. Note that the estimated coefficients on higher education is statistically significant for TE and SE and insignificant for TP and PTE. This suggest that the impact of higher education on productivity is mainly through the Technical Efficiency channel and the Scale Efficiency channel. In particular, the results in columns 1 and 4 also indicate U-shaped effects of technical efficiency (TE) and scale efficiency (SE) on total factor productivity, for the coefficients of the quadric term of higher education are estimated to be positively significant in the two regressions. For scale efficiency (SE), the result in column 4 suggests that higher education starts to have a positive impact on scale efficiency after the threshold value of 0.384 , which is slightly lower than the value estimated for TFP. In contrast, as the level term of higher education in the regression for technical efficiency (TE) is not significant, higher education would have an increasing positive effect on technical efficiency even at very low levels. This indicates that the development of higher education is of crucial importance for enhancing technical efficiency.

\section{Accounting for endogeneity}

As discussed in Section 2, to overcome the unobserved heterogeneity and jointly endogenous of the independent variables, we also use system GMM estimator as a robustness test. The results estimated using system GMM for Eq. (8) are presented in Table 4.

From the result in the first column in Table 4, we can see that the level term of higher education is estimated to be significantly negative while the quadric term of higher education is estimated to be significantly positive, indicating that the U-shaped relationship between higher education and TFP still holds under the GMM estimation. Similarly, consistent with the results in Table 3, the impact of higher education on scale efficiency (SE) is significant and U-shaped while that on technical efficiency (TE) is significantly positive at all levels of higher education. Overall, the results in Table 4 suggest that our main results in Sections 3.1-3.2 remain robust after controlling for endogeneity, which further prove the validity of our conclusion.

As for model specification tests, the p-values of the Sargan test and AR(2) test in Table 4 shows that the instruments used are appropriate and there is no evidence of second-order serial correlation in the estimation, suggesting our estimation results are valid. 
Table 4

Higher Education and TFP: System GMM Estimator

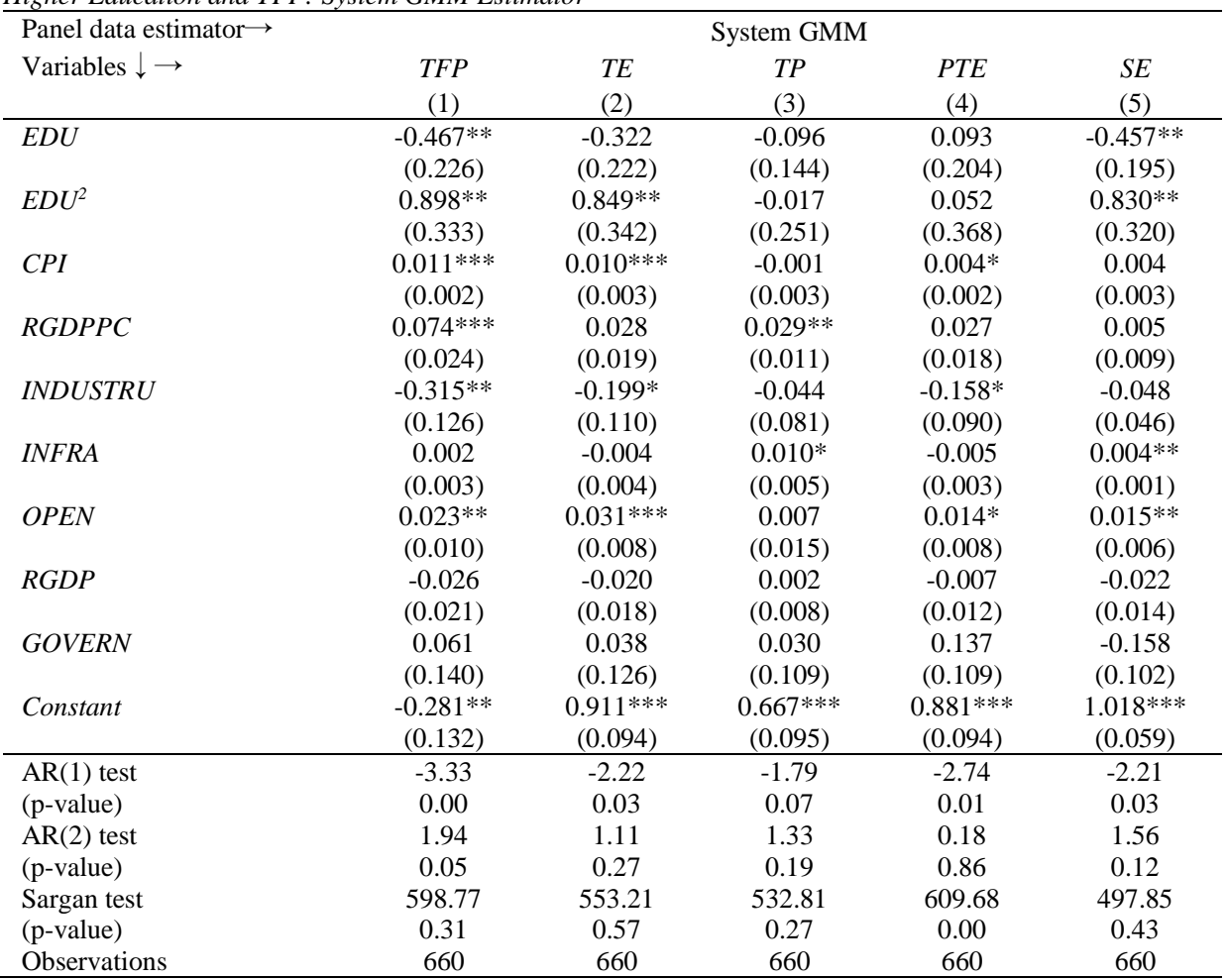

Notes: (1) Standard errors are in parentheses; $(2) *, * *$ and $* * *$ indicate that the coefficients are significant at the level of $10 \%, 5 \%$ and $1 \%$, respectively; (3) The p-values of first-order correlation test, second-order serial correlation test and overidentification test are shown in $\mathrm{AR}(1)$ test, $\mathrm{AR}(2)$ test and Sargan test, respectively.

\section{Conclusion}

In this paper, we investigate the effect of higher education on total factor productivity using provincelevel panel data from China over the period of 1995-2016. The results show that higher education has a significant U-shaped impact on total factor productivity with a threshold value of 0.323 , indicating that higher education development would have a positive impact on total factor productivity after the ratio of college graduates to population exceeds $32.3 \%$.

In addition, the results of this paper also reveal that the impact of higher education on total factor productivity is mainly through the Technical Efficiency channel and the Scale Efficiency channel. While the impact of higher education on scale efficiency remains U-shaped with a threshold value of 0.384 , its impact on technical efficiency is positive even at very low levels, implying a crucial role of higher education in promoting technical efficiency. 
This paper contributes to the existing literature in three main aspects. First, in contrast to the linear relationship discussed in the traditional literature, we find that there is in fact a nonlinear and U-shaped relationship between education and productivity. Second, we extend the literature by identifying two main channels (i.e., Technical Efficiency channel and Scale Efficiency channel) through which higher education can affect productivity. Third, we find that higher education in most provinces of China's is still below the threshold level, which means that developing higher education would be an important way of promoting productivity in China.

\section{References}

Ahsan, H., \& Haque, M. (2017). Threshold effects of human capital: Schooling and economic growth. Economics Letters, Elsevier, 156(C), 48-52. Https://doi.org/10.1016/j.econlet.2017.04.014

Barro, R. J. (1991). Economic growth in a cross section of countries. Quarterly Journal of Economics 106, 407 443. Https://doi.org/10.2307/2937943

Benhabib, J., Spiegel, M. (1994). The role of human capital in economic development: evidence from aggregate cross-country data. Journal of Monetary Economics, 34(2), 143-173. https://doi.org/10.1016/03043932(94)90047-7

Caves, D. W., Christensen, L. R., \& Diewert, W. E. (1982). Multilateral Comparisons of Output, Input, and Productivity Using Superlative Index Numbers. Economic Journal, 92(365), 73-86. https://doi.org/10.2307/2232257

Chen, J., Fleisher, B. (1996). Regional income inequality and economic growth in China. Journal of Comparative Economics, 22(2), 141-164. https://doi.org/10.1006/jcec.1996.0015

Chi, W. (2008). The role of human capital in China's economic development: Review and new evidence. China Economic Review, 19(3), 421-436. https://doi.org/10.1016/j.chieco.2007.12.001

Cohen, D., Soto, M. (2007). Growth and human capital: good data, good results. Journal of Economic Growth, 12(1), 51-76. https://doi.org/10.1007/s10887-007-9011-5

Demurger, S. (2001). Infrastructure development and economic growth: an explanation for regional disparities in China? Journal of Comparative Economics, 29(1), 95-117. https://doi.org/10.1006/jcec.2000.1693

Ding, S., \& Knight, J., 2011. Why has China growth so fast? The role of physical and human capital formation. Oxford Bulletin of Economics and Statistics 73(2), 141-174. http://dx.doi.org/10.1111/j.14680084.2010.00625.x

Fare, R., Grosskopf, S., Norris, M. (1994). Productivity Growth, Technical Progress, and Efficiency Change in Industrialized Countries. American Economic Review, 84(1), 66-83. http://dx.doi.org/10.2753/PET10611991361256

Fleisher, B., Chen, J. (1997). The coast-noncoast income gap, productivity and regional economic policy in China. Journal of Comparative Economics, 25(2), 220-236.

Fleisher, B., Hu, Y. F., Li, H. (2006). Higher education and worker productivity in China: educational policy, growth, and inequality. Working paper, Department of Economics, Ohio State University. 
Fleisher, B., Wang, X. (2004). Skill differentials, return to schooling, and market segmentation in a transition economic: the case of mainland China. Journal of Development Economics, 73, 715-728. http://dx.doi.org/10.1016/j.jdeveco.2002.12.002

Han, J., Shen, Y. (2015). Financial Development and Total Factor Productivity Growth: Evidence from China. Emerging Markets Finance \& Trade, 51(1), 261-274. https://doi.org/10.1080/1540496X.2014.998928

Hansen, B. E. (1999). Threshold effects in non-dynamic panels: Estimation, testing, and inference. J. Econometrics, 93(2), 345-368. https://doi.org/10.1016/S0304-4076(99)00025-1

Hanushek, E. A., Kimko, D. D. (2000). Schooling, labor-force quality, and the growth of nations. American Economic Review, 90(5), 1184-1208. https://doi.org/10.1257/aer.90.5.1184

Jeanneney, S., Hua, P., \& Liang, Z. (2006). Financial Development, Economic Efficiency, and Productivity Growth: Evidence from China. The Developing Economies, 44(1), 27-52. https://doi.org/10.1111/j.17461049.2006.00002.x

Kremer, S., Bick, A., Nautz, D. (2013). Inflation and growth: new evidence from a dynamic panel threshold analysis. Empirical Economics, 44(2), 861-878. https://doi.org/10.1007/s00181-012-0553-9

Krueger, A. B., Lindahl, M. (2001). Education for growth: Why and for whom? Journal of Economic Literature 39(4), 1101-1136. https://doi.org/10.2139/ssrn.223589

Levin, H. (1991). Raising Productivity in Higher Education. The Journal of Higher Education, 62(3), 241-262. https://doi.org/10.2307/1982281

Li, T., Lai, J., Wang, Y., \& Zhao, D., (2016). Long-run relationship between inequality and growth in postreform China: New evidence from dynamic panel model. International Review of Economics and Finance 41, 238-252. https://doi.org/10.1016/j.iref.2015.08.009

Mankiw, N. G., Romer, D., Weil, D. N. (1992). A contribution to the empirics of economic growth. Quarterly Journal of Economics, 1072, 407-457. https://doi.org/10.2307/2118477

Nasrul, I. (1995). Growth empirics: a panel data approach. Quarterly Journal of Economics, 113(1), 1127-1170. https://doi.org/10.1162/003355398555513

Nelson, R., Phelps, E. (1966). Investment in humans, technological diffusion, and economic growth. American Economic Review Papers and Proceedings, 56(1/2), 69-75. https://www.jstor.org/stable/1821269

Pritchett, L. (2001). Where has all the education gone? World Bank Economic Review, 15(3), 367-391. https://doi.org/10.1093/wber/15.3.367

Rogers, M. L. (2008). Directly unproductive schooling: How countries characteristics affect the impact of schooling on growth. European Economic Review, 52(2), 356-385. https://doi.org/10.1016/j.euroecorev.2007.03.001

Romer, P. (1990). Human capital and growth: Theory and evidence. Carnegie Rochester Conference Series on Public Policy, 32, 251-286.

Schündeln, M., Playforth, J. (2014). Private versus social returns to human capital: Education and economic growth in India. European Economic Review, 66, 283. https://doi.org/10.1016/j.euroecorev.2013.08.011

Song, S.L. (2018). Application of gray prediction and linear programming model in economic management, Mathematical Modelling of Engineering Problems, 5(1), 46-50. https://doi.org/10.18280/mmep.050107 
Temple, J. (1999). A positive effect of human capital on growth. Economics Letters, 65(1), 131-134. https://doi.org/10.1016/S0165-1765(99)00120-2

Wei, Y., Liu, X., Song, H., \& Romilly, P. (2001). Endogenous innovation growth theory and regional income convergence in China. Journal of International Development, 13, 153-168. https://doi.org/10.1016/S01651765(99)00120-2

Yao, S., \& Zhang, Z. (2001). On regional inequality and diverging clubs: A case study of contemporary China. Journal of Comparative Economics, 29, 466-484. https://doi.org/10.1006/jcec.2001.1726

Zhang, C., \& Zhuang, L. (2011). The composition of human capital and economic growth: Evidence from China using dynamic panel data analysis. China Economic Review, 22, 165-171. https://doi.org/10.1016/j.chieco.2010.11.001 